Volume 3 - Nomor 3 • Juni 2020

Pege (Hal.) : $66-76$

(C) Universitas Pamulang

JL.Surya Kencana No.1 Pamulang, Tangerang Selatan - Banten

Telp. (021) 7412566, Fax (021) 7412491

website. : Email : jurnalmarketing.unpam@gmail.com

\title{
Kepercayaan Sebagai Pemediasi Dampak Citra Merek dan Harga Terhadap Kepuasan Konsumen Gojek
}

\author{
Acai Sudirman ${ }^{1}$, Fitria Halim², Robetmi Jumpakita Pinem ${ }^{3}$ \\ 1,2Sekolah Tinggi IImu Ekonomi Sultan Agung \\ 3Universitas Diponegoro \\ Email: acaivenly@stiesultanagung.ac.id
}

\begin{abstract}
Ekosistem kemajuan teknologi informasi saat ini telah memasukin babak baru ditandai dengan munculnya perkembangan transportasi berbasis aplikasi. Saat ini, telah terjadi transformasi di bidang transportasi yang tidak disangka dapat menggantikan kebiasaan masyarakat menggunakan transportasi berbasis konvensional. Adapun tujuan utama dari penlitian ini adalah untuk mengetahui peran kepercayaan dalam menunjukkan hubungan citra merek dan harga terhadap kepuasan konsumen Gojek. Dalam menganalisa data yang diperoleh dari objek penelitian menggunakan model survei dengan pendekatan kuantitatif. Jumlah sampel yan digunakan sebagai responden sebanyak 100 orang. Data untuk analisis menggunakan uji validitas dan reliabilitas menggunakan outler model dan model struktural SEM sebagai representatif inner model. Berdasarkan hasil penelitian diperoleh bahwa kepercayaan tidak mampu menjadi mediasi hubungan antara citra merek kepada kepuasan konsumen. Selanjutnya variabel kepercayaan ternyata mampu menjadi mediasi hubungan antara harga kepada kepuasan konsumen
\end{abstract}

Keywords: Kepercayaan; Citra Merek; Harga; Kepuasan

\begin{abstract}
The ecosystem of information technology advances has entered a new era marked by the emergence of the development of application-based transportation. At present, there has been a transformation in the field of transportation that is unexpectedly able to replace people's habits of using conventional based transportation. This study aims to determine the role of trust in mediating the relationship between brand image and price on Gojek consumer satisfaction. Data analysis using a survey model with a quantitative approach. The number of samples used as respondents were 100 people. Data analysis used validity and reliability tests using SEM structural model as a representative of the inner model. The results of this study prove that trust cannot mediate the relationship between brand image and consumer satisfaction. Furthermore trust can mediate the relationship between price and customer satisfaction.
\end{abstract}

Keyword: Trust; Brand Image; Price; Satisfaction 


\section{A. PENDAHULUAN}

Kondisi yang terus berkembang dan seiring berjalannya waktu demikian juga kemajuan yang terdapat pada teknologi informasi dan komunikasi (TIK) secara khusus dalam bidang jaringan komputer (Hasibuan et al., 2020). Ekosistem kemajuan teknologi informasi saat ini telah memasukin babak baru ditandai dengan munculnya perkembangan transportasi berbasis aplikasi. Saat ini, telah terjadi transformasi di bidang transportasi yang tidak disangka dapat menggantikan kebiasaan masyarakat menggunakan transportasi berbasis konvensional. Kehadiran transportasi online saat ini memberikan alternatif bagi masyarakat sebagai konsumen untuk memilih jasa transportasi mana yang lebih memberikan pelayanan sesuai dengan kebutuhan dan keinginan mereka. Salah satu transportasi online yang saat ini populer digunakan masyarakat adalah transportasi berbasis aplikasi yang disebut dengan Gojek. Salah satu keunggulan yang dimiliki Gojek adalah tersedianya fitur-fitur dalam aplikasi yang didukung teknologi (Kuswanto et al., 2019). Selain itu, kehadiran Gojek memberikan lapangan pekerjaan bagi sebagian orang yang kehilangan pekerjaan, namun memiliki sepeda motor (Kathan, Matzler and Veider, 2016). Namun demikian, kehadiran kompetitor di bidang yang sama seperti Grab telah berimplikasi terhadap penurunan indeks top brand bagi Gojek. Berikut ini disajikan tabel 1 tentang posisi Gojek sebagai salah satu brand pilihan konsumen selama periode tahun 2017-2019.

Tabel 1. Peringkat Top Brand Transportasi Online di Indonesia Tahun 2017-2019

\begin{tabular}{|l|l|l|l|}
\hline Merek & TBI 2017 & TBI 2018 & TBI 2019 \\
\hline Gojek & $59,2 \%$ & $48,0 \%$ & $44,6 \%$ \\
\hline Grab & $28,2 \%$ & $44,9 \%$ & $43,1 \%$ \\
\hline
\end{tabular}

Sumber: www.topbrand-award.com

Sesuai dengan data di atas terlihat bahwa Gojek mengalami penurunan tingkat persentase top brand. Diketahui tahun 2017, persentase top brand Gojek sebesar 59,2\% kemudian tahun 2018 persentase top brand Gojek sebesar 48,0\% dan tahun 2019 persentase top brand Gojek sebesar $44,6 \%$. Hal ini tentunya disebabkan karena munculnya kompetitor di bidang yang sama seperti Grab dengan ditunjukkan angka persentase top brand selama 3 tahun berturut mengalami kenaikan. Kondisi ini tidak terlepas dari adanya berita negatif terkait kebocoran data pribadi penumpang, kasus bentrokan driver Gojek dengan ojek pangkalan, masalah jaringan dan keterlambatan penjemputan yang disebabkan karena kurang terampilnya beberapa driver Gojek dalam pengenalan tempat berdasarkan peta navigasi (Rahmidani, Kurniawati and Hanifa, 2018). Dengan kondisi ini, tentunya menjadikan masyarakat sebagai konsumen mempertimbangkan penggunaan transportasi Gojek sekaligus menjadi bahan evaluasi pihak manajemen Gojek dalam memperbaharui sistem pelayanan mereka. Hal lain yang patut dipertimbangkan adalah aspek kepercayaan terhadap suatu layanan jasa. Dengan dibangunnya konstruk kepercayaan yang terjalin antara konsumen dengan perusahaan memberikan, tentunya akan berimplikasi pada kemudahan bagi perusahaan dalam membina hubungan kerja sama dalam jangka panjang (Utami, 2015). Maka dari itu, untuk menjadi perusahaan yang unggul perlu adanya pengelolaan manajemen yang optimal sehingga perusahaan dapat memenuhi ekspektasi yang diharapkan konsumen (Haryoko, Septiani and Risnalinda, 2020). Berdasarkan uraian yang sudah dipaparkan, maka yang menjadi tujuan penelitian ini adalah mengetahui dampak dari kualitas pelayanan dan harga yang dimediasi oleh kepercayaan terhadap kepuasan konsumen. 


\section{B. KAJIAN LITERATUR}

\section{Citra Merek}

Aspek citra merek adalah salah satu aspek yang sangat penting dan perlu diperhatikan, oleh karena itu perlu dipertimbangkan sebagai salah satu stimulus dalam menjaga persepsi konsumen terhadap suatu produk. Berdasarkan hal tersebut maka citra merek merupakan suatu persepsi konsumen melalui adanya keyakinan terhadap suatu merek yang dipilih dan sesuai dengan apa yang diinginkan agar dapat mengkonsumsi produk tersebut. Atribut dari product mempunyai nilai yang baik atas brand tersebut yang didukung dengan melakukan pembelian secara berkelanjutan yang implikasinya terhadap rasa percaya yang tinggi dan tingkat kepuasan konsumen. Sesuai pendapat Sutisna dan Pawitra (2001), citra merek memiliki 3 indikator antara lain citra pembuat, citra pemakai dan citra produk.

\section{Harga}

Variabel harga adalah salah satu hal yang dapat menentukan apakah konsumen akan bersedia dan mampu dalam membeli suatu produk. Pada umumnya konsumen akan menggunakan harga sebagai indikator kepuasan, karena konsumen tersebut akan memeriksa harga suatu product yang di tawarkan sebelum melakukan kegiatan untuk membeli. Harga merupakan suatu ukuran atas sejumlah uang agar dapat memperoleh produk baik berupa barang maupun jasa (Kotler dan Gary, 2008). Urgensi harga pada suatu product berorientasi pada efektivitas strategik dalam pemasaran suatu produk sehingga perubahan harga yang tidak stabil akan menimbulkan sensitivitas terhadap perilaku konsumen untuk membeli. Menurut Kotler dan Gary (2008), aspek harga diukur dengan indikator keterjangkauan harga, diskon harga dan cara pembayaran.

\section{Kepercayaan}

Kepercayaan adalah variabel yang sering diuji dan pada umumnya akan muncul berdasarkan suatu proses. Kepercayaan dapat diciptakan karena adanya pengenalan akan suatu hal baik produk maupun yang lainnya. Kepercayaan akan mendorong orang untuk lebih mudah membina hubungan kerjasama dalam hal ini adalah hubungan antara konsumen dan produsen. Melalui adanya kepercayaan ditunjukkan oleh kualitas yang diperoleh dari pertama kali membeli atau merasakan jasa yang dimanfaatkan. Bisnis yang berkembang adalah bisnis yang dipelopori dengan kepercayaan dan perusahaan atau pemasar yang terpercaya. Banyak pakar yang meneliti mengenai kepercayaan, salah satu diantaranya menyatakan bahwa kepercayaan konsumen adalah kesimpulan konsumen yang di dasarkan atas pengetahuan yang dimilikinya mengenai karakteristik suatu produk (Mowen dan Miror, 2002). Dalam Priansa (2017), mengemukakan bahwa kepercayaan konsumen dibangun melalui dua dimensi, yaitu: trusting belief dan trusting intetntion.

\section{Kepuasan Konsumen}

Kepuasan konsumen adalah suatu impian yang diharapkan oleh perusahaan, karena tujuan konsumen dalam mengkonsumsi produk adalah Bagi suatu perusahaan atau organisasi, kepuasan merupakan pondasi untuk meraih sasaran yang akan dicapai dan Setiap pelanggan yang puas memilki inisiatif atau kecenderungan menciptakan hubungan yang ramah (Sudirman, Efendi dan Sri, 2020). Konsumen yang memperoleh kepuasan pada saat menggunakan barang yang diberikan, maka konsumen tersebut merasakan bahwa faktor stimulus seperti citra merek, harga dan kepercayaan telah sesuai dengan yang diharapkannya. Lebih lanjut Kotler dan Keller (2009) menyatakan bahwa kepuasan konsumen merupakan ungkapan serta perilaku yang muncul atas penilaian kinerja suatu produk atas dasar kesesuaian harapan dengan keinginan yang diperoleh, biasanya kepuasan konsumen akan terwujud apabila seseorang sudah mengkonsumsi produk yang dihasilkan oleh produsen. Menurut Lupiyoadi dan Hamdani (2006), ada empat komponen 
penting dalam hubungannya menjaga serta meningkatkan kepuasan konsumen, yaitu: kualitas produk atau jasa, harga produk atau jasa, kenyamanan prosedur, dan dukungan konsumen. Adapun kerangka konseptual yang dibangun pada penelitian ini adalah seperti pada Gambar 1.

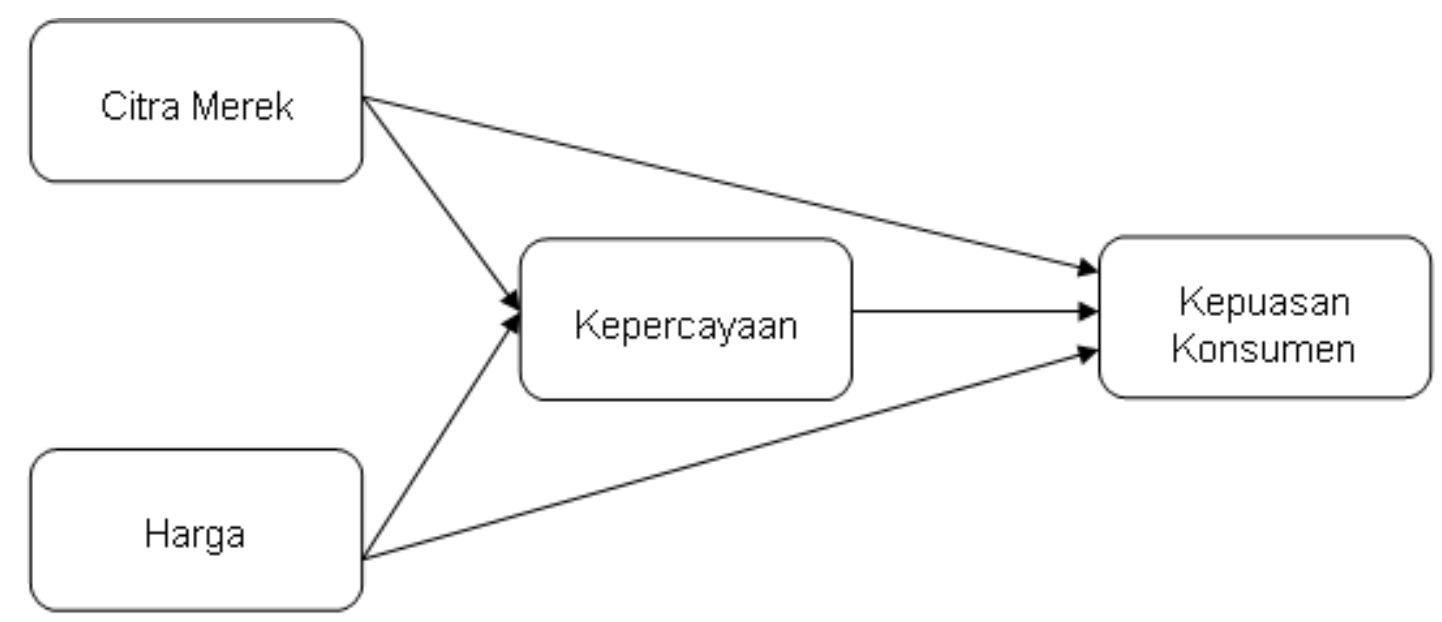

\section{Gambar 1. Kerangka Konseptual}

Hipotesis Penelitian

H1: Citra merek memiliki dampak terhadap kepercayaan

H2: Citra Merek memiliki dampak terhadap kepuasan konsumen

H3: Harga memiliki dampak terhadap kepercayaan

H4: Harga memiliki dampak terhadap kepuasan konsumen

H5: Kepercayaan memiliki dampak terhadap kepuasan konsumen

H6: Citra Merek memiliki dampak terhadap kepuasan konsumen dengan kepercayaan sebagai variabel mediasi

H7: Harga memiliki dampak terhadap kepuasan konsumen dengan kepercayaan sebagai variabel mediasi

\section{B. METODOLOGI PENELITIAN}

Pada penelitian ini, metode yang digunakan adalah melalui survei dengan pendekatan explanatory research (penelitian penjelasan) secara kuantitatif. Lokasi penelitian yang ditentukan adalah di Sekolah Tinggi Ekonomi Sultan Agung dengan alamat Jalan Surabaya No.19 Kelurahan Dwikora, Kecamatan Siantar Barat, Kota Pematangsiantar. Adapun proses pengumpulan data dilakukan dengan menggunakan kuesioner yang dibuat secara online dan dibagikan ke responden menggunakan tautan link. Populasi dalam penelitian ini adalah seluruh mahasiswa dan mahasiswi Sekolah Tinggi Ilmu Ekonomi Sultan Agung. Teknik perolehan sampel memakai nonprobability sampling dengan metode purposive sampling, responden bersedia menjawab pertanyaan yang diajukan serta kriteria lain yakni sampel pernah menggunakan transportasi Gojek lebih dari dua kali.. Populasi yang tidak diketahui secara pasti jumlah populasinya pengguna gojek diantara mahasiswa dan mahasiswi Sekolah Tinggi Ilmu Ekonomi Sultan Agung maka menurut Cooper and Emory (1996) diambil 100 responden untuk mewakili responden untuk mewakili pengguna Gojek.

\section{HASIL DAN PEMBAHASAN}


ISSN NO. (PRINT) 2598-0823, (ONLINE) 2598-2893

\section{Uji Validitas dan Reliabilitas}

Tabel 1. Uji Validitas Convergent Validity

\begin{tabular}{|l|l|l|l|l|l|l|l|}
\hline \multicolumn{2}{|c|}{ Citra Merek } & \multicolumn{2}{c|}{ Harga } & \multicolumn{2}{c|}{ Kepercayaan } & \multicolumn{2}{c|}{ Kepuasan Konsumen } \\
\hline $\mathrm{X} 1.1$ & 0.801 & $\mathrm{X} 2.1$ & 0.592 & $\mathrm{M} 1.1$ & 0.937 & $\mathrm{Y} 1.1$ & 0.608 \\
\hline $\mathrm{X} 1.2$ & 0.823 & $\mathrm{X} 2.2$ & 0.888 & $\mathrm{M} 1.2$ & 0.917 & $\mathrm{Y} 1.2$ & 0.857 \\
\hline $\mathrm{X} 1.3$ & 0.849 & $\mathrm{X} 2.3$ & 0.941 & & & $\mathrm{Y} 1.3$ & 0.887 \\
\hline & & & & & & $\mathrm{Y} 1.4$ & 0.883 \\
\hline
\end{tabular}

Tabel 1 menunjukkan bahwa model memiliki convergent validity yang baik. Hal ini mencerminkan bahwa semakin tinggi nilai loading factor pada setiap konstruk berarti semakin tinggi pula kontribusi indikator tersebut pada konstruk. Oleh karena itu, model ini menunjukkan validitas yang baik dan sesuai.

Tabel 2. Uji Reliabilitas

\begin{tabular}{|l|l|l|}
\hline \multicolumn{1}{|c|}{ Keterangan Variabel } & \multicolumn{1}{c|}{ Composite Reliability } & \multicolumn{1}{c|}{ Cronbach's Aplha } \\
\hline Citra Merek & 0.864 & 0.764 \\
\hline Harga & 0.857 & 0.751 \\
\hline Kepercayaan & 0.924 & 0.837 \\
\hline Kepuasan Konsumen & 0.887 & 0.826 \\
\hline
\end{tabular}

Sumber: hasil olahan data (2019)

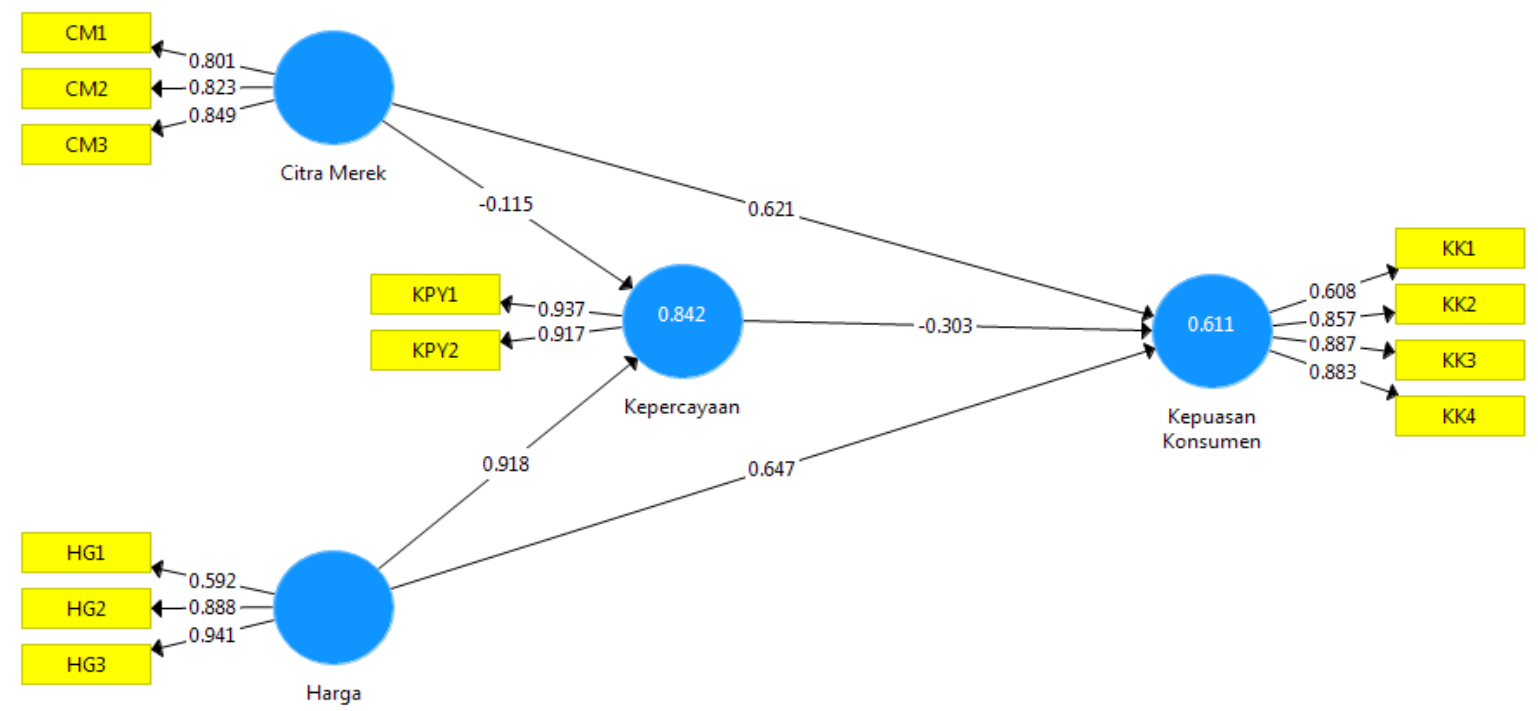

Gambar 2. Tampilan Outler Model

Sumber: (Output SmartPLS 3.0, 2019)

Pada pengujian reliabilitas di atas diperoleh nilai composite reliability untuk masingmasing variabel penelitian adalah di atas 0,7 yang dapat dijelaskan sebagai berikut: citra merek memperoleh 0.864 , harga memperoleh 0.857 , kepercayaan memperoleh 0.924 dan kepuasan konsumen memperoleh 0.887. Selanjutnya untuk nilai cronbach's alpha diperoleh nilai untuk masing-masing variabel di atas 0,60 hal ini menunjukkan bahwa semua variabel penelitian mempunyai nilai reliabilitas yang baik. Dengan nilai yang baik ini maka dapat digunakan sebagai gambaran dari kondisi keterkaitan antar variabel juga baik sehingga dapat dilakukan uji lebih lanjut. 


\section{Model Struktural}

Metode statistik yang digunakan untuk menguji hipotesis memakai multivariat Sructural Equation Modeling (SEM) dengan menggunakan software SmartPls versi 3.0. Adapun tahapan analisis data dengan model struktural meliputi: menata diagram jalur dan persamaan struktural, menilai indentifikasi model struktural, interpretasi model menggunakan uji hipotesis. Model struktural dengan PLS dapat dievaluasi yaitu dengan menggunakan nilai $R$ untuk variabel dependen, kemudian nilai koefisien path dan nilai $t_{\text {hitung }}$ untuk tiap path dalam hal uji signifikansi antar variabel dalam model. Nilai $R$ hitung digunakan dalam mengukur tingkat variasi perubahan variabel independen terhadap variabel dependen. Dapat dilihat bahwa apabial tinggi nilai $R^{2}$ semakin memiliki nilai yang besar maka dapat diartikan bahwa semakin baik prediksi model penelitian yang digunakan. Pada penelitian ini diperoleh hasil bahwa $R^{2}$ sebesar $0.75,0.5$, dan 0.25 untuk setiap laten endogen dalam model struktural dapat diinterpretasikan sebagai subtansial, moderat dan lemah. Hasil penelitian yang dilakukan menunjukkan hasil seperti pada Tabel 3 yaitu Nilai $R^{2}$ untuk variabel dependen penelitian kepercayaan dan kepuasan konsumen.

Tabel 3. Hasil Nilai $\mathbf{R}^{2}$ Inner Model

\begin{tabular}{|l|c|c|}
\hline \multicolumn{1}{|c|}{ Nama Variabel } & R Square & Interpretasi \\
\hline Kepercayaan & 0.842 & Subtansial \\
\hline Kepuasan Konsumen & 0.611 & Moderat \\
\hline
\end{tabular}

Tabel 3. Menunjukkan bahwa nilai $R^{2}$ pada vriabel kepercayaan adalah sebesar 0.842 , hal ini menunjukkan menunjukkan bahwa variabel independen (citra merek dan harga)mampu menjelaskan keragaman kepercayaan secara subtansial yaitu sebesar $84.2 \%$ dan sisanya sebesar $15.8 \%$ adalah variabel yang tidak termasuk pada variabel yang ada pada model dalam penelitian. Selanjutnya, nilai $R^{2}$ variabel kepuasan konsumen 0.611 , hal inimenunjukkan menunjukkan bahwa variabel independen (citra merek, harga dan kepercayaan) mampu menjelaskan keragaman kepuasan konsumen secara moderat yaitu sebesar $61.1 \%$ dan sisanya sebesar $38.9 \%$. Berdasarkan hal tersebut maka variabel yang digunakan pada penelitian ini sebenarnya sudah cukup baik untuk mencerminkan keadaan aktualnya. Selanjutnya untuk memperoleh nilai path coefficients sebagai dasar keterangan tingkat signifikansi dalam pengujian hipotesis maka dilakukan menggunakan hasil analisis menggunakan bootstrapping pada path coefficients. Skor path coefficients yang ditunjukkan oleh nilai thitung harus di atas nilai $t_{\text {tabel }}$ dengan taraf signifikansi alpha $5 \%$ sehinga diperoleh hasil yaitu sebesar 1,96. Kemudian hasil tersebut dilakukan perbandingan $t_{\text {hitung }}$ dengan $t_{\text {tabel }}$, jika nilai $t_{\text {hitung }}>t_{\text {tabel }}(1,96)$, maka berdasarkan nilai ini dapat diartikan bahwa perumusan hipotesis ditolak. Untuk lebih jelas hasil analisis dengan proses bootstrapping pada path coefficients dengan tingkat kepercayaan 5\% secara lengkap disajikan pada Gambar 3.

Tabel 4. Hasil Uji Path Coefficients

\begin{tabular}{|l|c|c|c|c|}
\hline Path Antar Variabel & Koefisien & thitung & $\boldsymbol{P}$-Value & Kesimpulan \\
\hline $\begin{array}{l}\text { Citra Merek >> } \\
\text { Kepercayaan }\end{array}$ & 0.918 & 3.057 & 0.002 & Signifikan \\
\hline $\begin{array}{l}\text { Citra Merek >> } \\
\text { Kepuasan Konsumen }\end{array}$ & 0.647 & 8.708 & 0.000 & Signifikan \\
\hline Harga>>Kepercayaan & 0.918 & 57.218 & 0.000 & Signifikan \\
\hline $\begin{array}{l}\text { Harga >> Kepuasan } \\
\text { Konsumen }\end{array}$ & 0.647 & 4.543 & 0.000 & Signifikan \\
\hline $\begin{array}{l}\text { Kepercayaan >> } \\
\text { Kepuasan Konsumen }\end{array}$ & -0.303 & 2.217 & 0.027 & Signifikan \\
\hline
\end{tabular}


Sumber: hasil olahan data (2019)

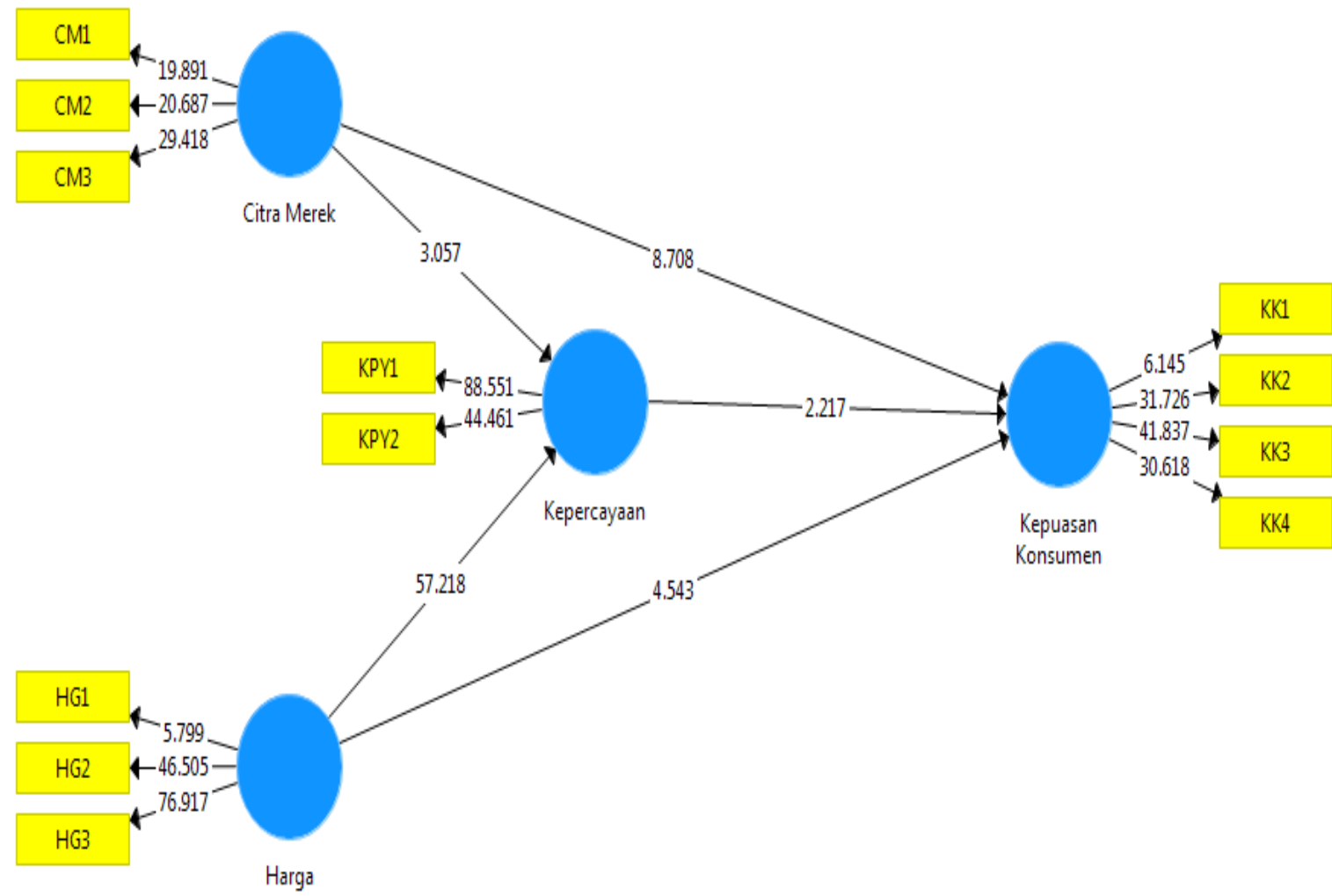

Gambar 3. Tampilan Inner Model

Sumber: (Output SmartPLS 3.0, 2019)

Hasil output yang disajikan pada tabel 4 di atas memperlihatkan hasil path coefficientsvariabel citra merek berpengaruh signifikan secara langsung terhadap kepercayaan dengan nilai thitung sebesar 3.057 lebih besar dari $t_{\text {tabel }} 1,96$. Selanjutnya hasil path coefficients variabel citra merekberpengaruh signifikan secara langsung terhadap kepuasan konsumen dengan nilai $t_{\text {hitung }}$ sebesar 8.708 lebih besar dari $t_{\text {tabel }} 1,96$. Kemudian path coefficients variabel harga berpengaruh signifikan secara langsung terhadap kepercayaan dengan nilai $t_{\text {hitung }}$ sebesar 57.218 lebih besar dari $t_{\text {tabel }} 1,96$. Selanjutnya hasil path coefficients variabel harga berpengaruh signifikan secara langsung terhadap kepuasan konsumen dengan nilai $t_{\text {hitung }}$ sebesar 4.543 lebih besar dari $t_{\text {tabel }} 1,96$. Lebih lanjut path coefficients variabel kepercayaan berpengaruh signifikan secara langsung terhadap kepuasan konsumen dengan nilai thitung sebesar 2.217 lebih besar dari tabel 1,96 . Kemudian, hasil uji Indirect Effect dari variabel kepercayaan merupakan pemediasi hubungan antara citra merek dan harga terhadap kepuasan konsumen, dapat dilihat melalui uji hubungan tidak langsung seperti yang disajikan pada Tabel 5 :

Tabel 5. Hasil Uji Indirect Effect

\begin{tabular}{|c|c|c|c|c|}
\hline Path Antar Variabel & Koefisien & thitung & P-Value & Kesimpulan \\
\hline Citra $\quad$ Merek >> & 0.035 & 1.875 & 0.061 & Tidak \\
\hline $\begin{array}{ll}\text { Kepuasan } & \text { Konsumen } \\
\text { yang } & \text { Dimediasi } \\
\text { Kepercavaan } & \end{array}$ & & & & Memediasi \\
\hline
\end{tabular}


ISSN No. (PRINT) 2598-0823, (ONLINE) 2598-2893

\begin{tabular}{|l|l|l|l|l|}
\hline $\begin{array}{l}\text { Harga >> Kepuasan } \\
\text { Konsumen } \\
\text { Dimediasi Kepercayaan }\end{array}$ & -0.278 & 2.208 & 0.028 & Memediasi \\
\hline
\end{tabular}

Tabel 5 diperoleh bahwa variabel kepercayaan hanya mampu memediasi hubungan antara harga terhadap kepuasan konsumen, sedangkan untuk hubungan citra merek terhadap kepuasan konsumen, kepercayaan bukan merupakan variabel mediasi.

Berdasarkan hasil analisis data yang diperoleh diatas diketahui citra merek dapat meningkatkan kepercayaan dengan nilai thitung $3.057 \geq 1.96$ serta nilai $P$ yang diperoleh $0.002<0.05$. Maka dari itu, senada dengan penelitian (Prasetya, Kumadji and Yulianto, 2014), (Basuki and Devi, 2016), (Walandouw, Mekel and Soegoto, 2014), (Rivai and Wahyudi, 2019) dimana masing-masing dari penelitian tersebut menyatakan bahwa citra merek terbukti dapat meningkatkan kepercayaan. Lebih lanjut, citra merek juga memiliki dampak terhadap kepuasan konsumen dengan perolehan thitung sebesar $8.708 \geq 1.96$ dan nilai $P$ sebesar $0.000<0.05$ sehingga hasil ini sejalan dengan temuan (Hartono and Wahyono, 2015), (Kurniawati, Suharyono and Kusumuwati, 2014), (Haryono and Octavia, 2020), (Fatoni, 2018) temuan mereka juga menunjukkan hal yang sama yaitu citra merek memiliki dampak terhadap kepuasan konsumen.

Kemudian harga diketahui memiliki kontribusi terhadap tingkat kepercayaan dengan perolehan thitung sebesar $53.569 \geq 1.96$ dan nilai $P$ sebesar $0.000<0.05$, sehingga hasil penelitian ini sependapat dengan temuan (Harjunawati and Hendrasih, 2018), (Wijaya and Wismantoro, 2017), (Pratama and Santoso, 2018) yang mengemukakan dalam temuannya bahawa variabel harga memiliki kontribusi terhadap tingkat kepercayaan. Namun hal ini berbeda dengan temuan pada penelitian (Andilala, Muh, Bachtiar, Fitra and Saputra, 2018) yang justru dalam penelitiannya menyatakan bahwa harga tidak memiliki kontribusi terhadap tingkat kepercayaan namun tergantung pada bagaimana tingkat kebutuhan dan kepentingan konsumen terhadap suatu produk yang dikonsumsi sehingga akan mempengaruhi tingkat kepercayaan.

Untuk kontribusi harga terhadap kepuasan konsumen juga menunjukkan hal yang positif dimana perolehan thitung sebesar $4.195 \geq 1.96$ dan nilai $P$ sebesar $0.000<0.05$, maka dapat diartikan temuan dalam penelitian ini sesuai dengan temuan (Purnamasari, 2015), (Harjati and Venesia, 2015), (Prasetio, 2012), (Sulistiyana, Hamid and Azizah, 2015), (Maulana, 2016) yang juga menunjukkan pada hasil penelitiannya bahwa kontribusi harga terhadap kepuasan konsumen berpengaruh positif.

Selanjutnya, untuk tingkat pengaruh kepercayaan terhadap kepuasan konsumen juga menunjukkan hasil yang baik dilihat dari perolehan thitung dengan nilai $2.217 \geq 1.96$ serta hasil yang didapatkan pada nilai $P$ adalah $0.027<0.05$, sehingga hasil ini sejalan dengan temuan (Semuel and Wijaya, 2017), (Usvela, Qomariah and Wibowo, 2019), (Sutrisno, Cahyono and Qomariah, 2017), (Andhini and Khuzaini, 2017) dimana masing-masing temuannya mengungkapkan bahwa terdapat pengaruh kepercayaan terhadap kepuasan konsumen. Sedangkan untuk efek mediasi diketahui kepercayaan tidak mampu memedias hubungan antara citra merek terhadap kepuasan konsumen dengan ditunjukkan perolehan sebesar $1.875 \leq 1.96$ dan nilai $P$ sebesar $0.061>0.05$, namun berdasarkan hasil yang diperoleh dapat diartikan bahwa variabel kepercayaan mampu menjadi mediasi hubungan harga terhadap kepuasan konsumen dengan dibuktikan perolehan thitung dengan nilai 2.208 $\geq 1.96$ serta nilai $P$ diperoleh dengan nilai $0.028<0.05$.

\section{E. KESIMPULAN}

Jurnal Pemasaran Kompetitif, Vol. 3, No. 3 Juni 2020 
Temuan yang diperoleh dari penelitian adalah citra merek ternyata berpengaruh terhadap kepercayaan. selanjutnya, citra merek juga ada pengaruhnya terhadap kepuasan konsumen. Selanjutnya variabel harga berpengaruh terhadap kepercayaan. Kemudian harga memiliki pengaruh nyata terhadap kepuasan konsumen. kepercayaan memiliki hubungan terhadap kepuasan konsumen. Sementara kepercayaan tidak mampu menjadi mediasi antara citra merek terhadap kepuasan konsumen. Selanjutnya, kepercayaan ternyata mampu menjadi mediasi hubungan antara harga kepada kepuasan konsumen.

\section{DAFTAR PUSTAKA}

Andhini, A. and Khuzaini (2017) 'Pengaruh Transaksi Online Shopping, Dan Kepercayaan Konsumen Terhadap Kepuasan Konsumen Pada E-Commerce', Jurnal Ilmu dan Riset Manajemen, 6(7), pp. 1-23.

Andilala, Muh, E. A., Bachtiar, Fitra, A. and Saputra, M. C. (2018) 'Analisis Pengaruh Harga, Persepsi Ukuran, Persepsi Reputasi, dan Kualitas Layanan Terhadap Kepercayaan Konsumen Dalam Menggunakan Transportasi Online (Studi Kasus: GO-JEK Indonesia)', Jurnal Pengembangan Teknologi Informasi dan IImu Komputer, 2(4), pp. 1638-1647.

Basuki, K. and Devi, N. (2016) 'Pengaruh Citra Merek dan Promosi Penjualan Terhadap Kepuasan Dengan Kepercayaan Nasabah Sebagai Variabel Intervening Pada PT. Allianza Life Indonesia di Jakarta', Media Manajemen Masa, 3(2), pp. 74-88.

Cooper dan Emory, 1996. Metode Penelitian Bisnis, Jakarta:Erlangga.

Fatoni, A. N. (2018) 'Pengaruh Citra Merek, Kualitas Pelayanan dan Nilai Pelanggan Terhadap Kepuasan Konsumen Pada Distro di Yogyakarta', Jurnal Ekobis Dewantara, $1(4)$, pp. 53-62.

Harjati, L. and Venesia, Y. (2015) ‘Pengaruh Kualitas Layanan dan Persepsi Harga Terhadap Kepuasan Pelanggan Pada Maskapai Penerbangan Tiger Air Mandala', E-Journal WIDYA Ekonomika, 1(2015), pp. 64-74.

Harjunawati, S. and Hendrasih, I. (2018) 'Pengaruh Kualitas Produk, Kualitas Pelayanan dan Persepsi Harga terhadap Loyalitas Pelaggan', Aktiva: Jurnal Penelitian Ekonomi dan Bisnis, 2(2), pp. 1-10.

Hartono, A. and Wahyono (2015) 'Pengaruh Citra Merek dan Kualitas terhadap Kepuasan Konsumen melalui Keputusan Pembelian sebagai Variabel Intervening', Management Analysis Journal, 4(2), pp. 153-162. doi: 10.15294/maj.v4i2.7824.

Haryoko, U. B., Septiani, F. and Risnalinda (2020) 'Pengaruh Kualitas Layanan Terhadap Kepuasan Pelanggan Starbucks Coffee Plaza Kampung Kemang', Jurnal Pemasaran Kompetitif, 3(2), pp. 40-47.

Haryono, N. and Octavia, R. (2020) 'Analisis Pengaruh Citra Merek Dan Mutu Layanan Terhadap Kepuasan Konsumen Serta Dampaknya Terhadap Loyalitas Konsumen', INDEPT, 4(1), pp. 20-27.

Hasibuan, A. et al. 2020. E-Business: Implementasi, Strategi dan Inovasinya. Cetakan 1. Medan: Yayasan Kita Menulis.

Kathan, W., Matzler, K. and Veider, V. (2016) 'The sharing economy: Your business model's friend or foe?', Business Horizons. Kelley School of Business, Indiana University, 59(6), pp. 663-672. doi: 10.1016/j.bushor.2016.06.006.

Kotler, Philip dan Gary Amstrong. 2008. Prinsip-prinsip Pemasaran. Edisi XII, Jilid 1. Jakarta: Erlangga.

Kotler, Philip dan Kevin lane Keller. 2009. Manajemen Pemasaran. Jilid 2, Edisi Ketigabelas. Jakarta: Erlangga.

Kurniawati, D., Suharyono and Kusumuwati, A. (2014) 'Pengaruh Citra Merek dan Kualitas 
Produk Terhadap Kepuasan dan Loyalitas Pelanggan', Jurnal Administrasi Bisnis, 14(2), pp. 1-9. Available at: http://administrasibisnis.studentjournal.ub.ac.id/index.php/jab/article/view/583.

Kuswanto, A. et al. (2019) 'The determinants of customer loyalty in the Indonesian ridesharing services: offline vs online', Innovation \& Management Review, ahead-ofp(ahead-of-print). doi: 10.1108/inmr-05-2019-0063.

Lupiyoadi, Rambat dan A. Hamdani. 2006. Manajemen Pemaasaran Jasa. Edisi Kedua. Jakarta: Salemba Empat.

Maulana, A. S. (2016) 'Pengaruh Kualitas Pelayanan Dan Harga Terhadap Kepuasan Pelanggan PT. TOl', Jurnal Riset Manajemen dan Bisnis (JRMB) Fakultas Ekonomi UNIAT, 7(2), pp. 113-125. doi: 10.36226/jrmb.v4i1.240.

Mowen, Jhon C dan Michael Minor. 2002. Perilaku Konsumen. Jilid 2, Edisi Kelima. Jakarta: Erlangga.

Prasetio, A. (2012) 'Pengaruh Kualitas Pelayanan Dan Harga Terhadap Kepuasan Pelanggan', Management Analysis Journal, 1(4), pp. 37-44. doi: 10.36226/jrmb.v4i1.240.

Prasetya, C. H. A., Kumadji, S. and Yulianto, E. (2014) 'Pengaruh Citra Merek, Kualitas Produk Terhadap Kepercayaan Serta Keputusan Pembelian', Jurnal Administrasi Bisnis S1 Universitas Brawijaya, 15(2), p. 84754.

Pratama, D. W. and Santoso, S. B. (2018) 'Pengaruh Citra Merek, Kualitas Produk dan Harga Terhadap Keputusan Pembelian melalui Kepercayaan Konsumen pada Produk Stuck Original', Diponegoro Journal of Management, 7(2), pp. 1-11.

Priansa, Donni Juni. 2017. Perilaku Konsumen dalam Persaingan Bisnis Kontemporer. Bandung: Alfabeta.

Purnamasari, Y. (2015) 'Pengaruh Kualitas Produk Dan Harga Terhadap Kepuasan Konsumen Produk M2 Fashion Online Di Singaraja Tahun 2015', Jurnal Jurusan Pendidikan Ekonomi (JJP), 5(1), pp. 1-12.

Rahmidani, R., Kurniawati, T. and Hanifa, O. (2018) 'Pengaruh Harga Dan Kualitas Layanan Terhadap Loyalitas Pelanggan Gojek Dengan Kepuasan Pelanggan Sebagai Variabel Mediasipada Mahasiswa Universitas Negeri Padang', Jurnal Manajemen Pemasaran, 1(4), pp. 794-803.

Rivai, A. R. and Wahyudi, T. A. (2019) 'Pengaruh Persepsi Kualitas Dan Citra Merek Terhadap Loyalitas Pelanggan Dengan Kepercayaan Pelanggan Dan Kepuasan Pelanggan Sebagai Variabel Mediasi', KALBISOCIO: Jurnal Bisnis dan Komunikasi, 4(2), pp. 307-316. doi: 10.36226/jrmb.v4i2.271.

Semuel, H. and Wijaya, V. (2017) 'Analisis Kepercayaan, Motivasi Dan Kepuasan Orang Tua Siswa Sma Kristen Petra 1 Surabaya', Jurnal Manajemen Pemasaran, 11(1), pp. 1-10. doi: 10.9744/pemasaran.11.1.1-10.

Soelasih, Y. (2016) 'Pengaruh Experiental Marketing dan Citra Merek Terhadap Kepuasan Penumpang Kereta Api Bisnis', MIX: Jurnal IImiah Manajemen, VI(3), pp. 387-398.

Sudirman, A., Efendi, Sri, H. 2020. Kontribusi Harga dan Kepercayaan Konsumen Untuk Membentuk Kepuasan Pengguna Transportasi Berbasis Aplikasi. Journal of Business and Banking, 9(2).

Sulistiyana, R. T., Hamid, D. and Azizah, D. F. (2015) 'Pengaruh Fasilitas Wisata Dan Harga Terhadap Kepuasan Konsumen (Studi Pada Museum Satwa)', Jurnal Administrasi Bisnis S1 Universitas Brawijaya, 25(2), p. 86214.

Sunardi, N., \& Lesmana, R. (2020). Pelaksanaan Alokasi Dana Desa Terhadap Manajemen Keuangan Desa dalam Meningkatkan Efektivitas Program Desa Sejahtera Mandiri Di Desa Cihambulu, Kec. Pabuaran, Kab. Subang. Jurnal SEKURITAS (Saham, Ekonomi, Keuangan dan Investasi), 3(3), 277-288.

Sutisna dan Prawita. 2001. Perilaku Konsumen dan Komunikasi Pemasaran. Jakarta: Ghalia 
Indonesia.

Sutrisno, Cahyono, D. and Qomariah, N. (2017) 'Analisis Kualitas Pelayanan , Kepercayaan serta Citra Koperasi terhadap Kepuasan dan Loyalitas Anggota', Jurnal Sains Manajemen \& Bisnis Indonesia, 7(2), pp. 157-174.

Usvela, E., Qomariah, N. and Wibowo, Y. G. (2019) 'Pengaruh Brand Image, Kepercayaan , Dan Nilai Pelanggan Terhadap Kepuasan Pelanggan Herbalife', Jurnal Manajemen dan Bisnis Indoensia, 5(2), pp. 300-312.

Utami, S. (2015) 'THE INFLUENCE OF CUSTOMERS ' TRUST ON CUSTOMER LOYALTY', International Journal of Economics and Management, III(7), pp. 638-653. Available at: http://ijecm.co.uk/.

Walandouw, G., Mekel, P. and Soegoto, A. (2014) 'Kualitas Pelayanan Dan Citra Merek Pengaruhnya Terhadap Kepercayaan Nasabah Bertransaksi E-Banking Melalui Kartu Debit Taplus Bni', Jurnal Emba, 2(2), pp. 1261-1271.

Wijaya, V. S. and Wismantoro, Y. (2017) 'Pengaruh Kualitas Produk Dan Persepsi Harga Terhadap Kepuasan Nasabah Melalui Kepercayaan Nasabah Asuransi Jiwasraya Cabang Kudus', Jurnal Penelitan Ekonomi dan Bisnis, 2(2), pp. 101-113. doi: 10.33633/jpeb.v2i2.2276.

www.topbrand-award.com. Html. (diakses pada Maret 2020) 